\section{Ministry's ambitions still higher}

EFFORTS to increase Japan's research and development expenditure to a staggering 3 per cent of gross national product (GNP), compared with the present 2.44 per cent (a couple of tenths of a per cent more than most Western nations) are once again being called for by the Ministry of International Trade and Industry (MITI).

The "three-per-cent-of-GNP" goal was first proposed in 1980 and its re-emergence at a time when the government is calling for more severe budget restraint than ever before is a symptom of MITI's current "high technology" fever: the belief that the holy trinity of "biotechnology, electronics and new materials" will guarantee Japan's prosperity into the twenty-first century. According to MITI estimates, electronics and information processing equipment will have a market of around 24 million million yen ( $£ 74,000$ million) in 1990 and new materials and biotechnology Y10 million million and Y4-7 million million respectively in AD 2000.

To attain the three per cent level would require a massive change in the way research and development in Japan is supported. At present, the government provides only 27 per cent of the nation's research funds, while the rest of the money comes from (and is spent by) industry, in stark contrast with the United States and the United Kingdom where a little over 50 per cent of support is put up by government. Even after allowing for the very much higher level of governmentsponsored defence research in the United States, the Japanese Government still provides relatively less support for research $(25$ per cent against the US 33 per cent). The

\section{MITI's proposals}

THE Ministry of International Trade and Industry (MITI) is basing this year's budget proposals on a carefully integrated set of strategic proposals, as follows:

- A series of tax breaks - worth Y100,000 million a year - is being planned to stimulate research and development in high technology. And MITI hopes to see in the next fiscal year tax credits, for as much as 50 per cent of increases in basic research expenditures, together with 50 per cent depreciation allowances for new research equipment and more favourable accounting procedures.

- The problem of the lack of venture capital for small companies is to be tackled. Tax-free loans for small companies in high technology, including software development companies, are proposed. MITI estimates there are some $3,000-5,000$ small companies which could benefit from government support.

- MITI is planning to reorganize its own research efforts and to change its own rules three per cent level would, however, change all that, requiring the government to take a 40 per cent share in the nation's research budget.

Such an increase seems scarcely possible, but MITI believes that Japanese industry cannot carry out the large-scale basic research needed in high technology without substantial government support. And alongside a simple direct increase in funding of the government's own research laboratories, MITI is proposing a series of moves to stimulate "high-tech" industrial research - and to link more tightly government and industrial research.

To bolster public support for the expansion of high technology research, MITI has made much of recent reports of the increasing "American threat": news that the industrial plant and equipment in the United States is now on average newer than in Japan and that US capital investment is increasing while that of Japan is decreasing.

MITI's wild enthusiasm for high technology is at least partly motivated by a desire to restore the prestige and influence it enjoyed in the high growth era of the 1960s. The industries it fostered then and which were the locomotives of the Japanese economic miracle - steel, petrochemicals and paper - are now in decline. Despite recent MITI efforts to enter into the rapidly expanding telecommunications field, the Ministry of Posts and Telecommunications remains in control. MITI is now looking to high technology to save its own prestige as well as to guarantee Japan's future prosperity.

MITI's war cry as it drafts next year's budget request is bound to sharpen ten-

so that joint government-industry research, rather than only contract work, can take place inside government laboratories. MITI's numerous laboratories in Tsukuba Science City have superb modern facilities: access to MITI and its trained personnel will make joint research an attractive prospect for industry. And the resulting patents and their use by third parties will not be controlled by the government as at present but jointly by industry and government.

- MITI has an eye out for possible trade problems with other countries too. Next year it plans to set up a new institute, provisionally named the International Research Cooperation Japan Trust, modelled on the Humboldt Foundation of West Germany. Its aim is to avoid trade friction by promoting joint research projects. Postdoctoral research workers will be invited to Japan for one or two years at a time with the aid of fund which with luck will be provided in next year's budget and by donations from private industry.

Alun Anderson sions with the Ministry of Education, Science and Culture (MESC), the chief source of support for the universities and their "basic science". MITI officials are openly dismissive of MESC for failing to get the universities to work effectively with industry or to move quickly enough as research priorities change. But to those in the universities it seems that MITI policies reduce their role to that of supplying trained personnel to industrial laboratories and even that is not an easy job.

In biotechnology, for example, there seems little recognition of the need to maintain a large pool of researchers doing truly fundamental research on the many diverse specializations that will need to be brought to bear for success. Although money for molecular biology research is available, there is a considerable shortage of staff.

Indeed, it is doubtful whether Japanese biotechnology companies could have reached their present stage of development without the return of many scientists who were working in laboratories in the United States and Europe. When it comes to the science budget, though, the power and influence of MITI (and the Science and Technology Agency) outweighs that of MESC, and there is little possibility, even if major increases in research spending are made, that the universities will benefit much from them.

Alun Anderson

\section{AIDS London scare ends}

BLOOD tests of London laboratory technicians thought to have been exposed to acquired immune deficiency syndrome (AIDS) virus when a vacuum pump leaked have proved negative. The scare occurred at the Middlesex Hospital early in June when the retrovirus HTLV-III was being coated on plastic for antibody tests.

It was claimed by the trade union ASTMS (Association of Scientific, Technical and Managerial Staffs) that a vacuum pump used in this process was deficient. Professor John Patterson, head of the hospital's virology department, has denied this, saying that the pump was outside the Class 1 safety cabinet in which the plating experiment was being carried out. He said that it was not possible to guarantee that an aerosol had not been discharged into the air, but that it was very unlikely. There were three traps in the pump line, the last one a dry trap, which had remained dry.

Patterson says that it was right that ASTMS should be concerned, but that their fears had been disspelled. Mr Pike, safety representative of ASTMS at the Middlesex Hospital reported that a meeting between ASTMS and hospital representatives agreed that safety procedures would be reviewed and the pathology laboratory involved upgraded to full Category 3 status. Marcus Chown 